\title{
Longitudinal Study of Factors Relating to Recovery from Childhood Stuttering
}

\author{
Masashi Shiomi ${ }^{1,2)}$, Nobufumi Yasuda ${ }^{2)}$ and Atsuhiko Ota ${ }^{2)}$
}

\begin{abstract}
Investigations of factors relating to recovery from childhood stuttering are usually based on univariate analysis. Due to this, these factors may not be properly understood, because the relationship between a specific characteristic and recovery from stuttering may be confounded by other factors, or because the relationship between a characteristic and recovery may differ according to whether the subject possesses another factor concurrently. We conducted a longitudinal study of stuttering children who received treatment at stuttering treatment facilities and performed a multivariate analysis by sex and time from onset. We examined the associations between recovery and pre-treatment characteristics by following 97 stuttering children (average age at first consultation at a research institute, 55.7 months; range, 24-111 months) who received stuttering treatment from speech-language-hearing therapists in 14 stuttering treatment facilities. The average time from onset until recovery or end of observation was 36.0 months (range, 5-83 months). Characteristics associated with recovery from stuttering on univariate analysis were simultaneously entered into a proportional hazards model. In this model, stuttering developmental phase was identified as a factor independently related to recovery on analysis of all subjects and analysis by sex. On analysis by time from onset, pre-treatment characteristics were associated with recovery only in the group that received consultations at a stuttering treatment facility within 24 months of onset. An onset age of 24 months or earlier, female sex and a stuttering developmental phase of 1 were found to be associated with a high recovery rate in a mutually independent manner. The period when predictive factors of stuttering recovery can be observed is within 24 months of onset; prognosis for stuttering treatment begun within this time frame can be predicted based on onset age, sex, and pre-treatment developmental phase.
\end{abstract}

Key words: childhood stuttering, predictive factors, sex, time from onset, stuttering developmental phase

\section{幼児期吃音の治癒に関連する因子を明らかにする縦断研究}

$$
\text { 塩見 将志 }{ }^{1,2)} \text { 安田 誠史 }{ }^{2)} \text { 太田 充彦 } 22
$$

\footnotetext{
${ }^{1)}$ Department of Speech, Language and Hearing Pathology, Kochi Rehabilitation Institute: 1139-3 Otsu, Takaoka-cho, Tosa-shi, Kochi 781-1102, Japan

${ }^{2}$ Department of Public Health, Kochi Medical School: Kohasu, Okoh-cho, Nankoku-shi, Kochi 783-8505, Japan

高知リハビリテーション学院言語療法学科 ${ }^{1}$ ： ₹ 781-1102 高知県土佐市高岡町乙 1139-3

高知大学医学部公衆衛生学教室 ${ }^{2)}$ : $7783-8505$ 高知県南国市岡豊町小蓮

2010 年 4 月 23 日受稿 2010 年 10 月 1 日受理
} 
要 約：吃音治療施設で, 言語聴覚士による治療を受けた吃音児 97 名を対象とする縦断研 究を実施して, 性別と発吃からの期間別に多变量解析を行い, 吃音児の治療前の特性と治癒と の関連を検討した。単変量解析で吃音治癒との関連が見られた特性を同時に投入した比例八 ザードモデルでは, 標本全員を用いた解析でも性別解析でも, 吃音の進展段階が治癒の独立し た関連因子として検出された。発吃からの期間別解析では，発吃から 24 カ月以内に吃音治療 施設を受診した群でのみ，児の治療前の特性と治癒との関連が認められ，発吃年齢が 24 カ月 以下であること, 女であること, 進展段階が 1 相であることが, 相互に独立して, 高い治癒率 に関連した。吃音治癒を予知する因子の把握が可能な期間は発吃から 24 カ月以内であり, こ の期間中に開始する吃音治療については, 発吃年齢, 性別そして治療前の進展段階に基づいて 予後を予測できる.

索引用語：幼児期吃音, 予後関連因子, 性別, 発吃からの期間, 吃音進展段階

\section{Introduction}

The cumulative incidence of childhood stuttering is $4.99 \%$ by 3 years of age and $5.19 \%$ by 9 years of age ${ }^{1)}$. The recovery rate is between $62 \%$ and $79 \%^{2,3)}$ and may reflect the maturation of speech-motor control mechanisms ${ }^{4}$. Recovery from childhood stuttering usually occurs within 24 months of onset, with recovery becoming more difficult after 24 months $^{1,5}$.

Kalinowski and Saltuklaroglu ${ }^{6)}$ reported that there are no personal characteristics that indicate whether subjects will recover from childhood stuttering. However, several other studies have reported characteristics related to recovery from childhood stuttering. Riper ${ }^{7}$ and Conture $^{8)}$ reported that stuttering can easily become chronic if the main symptoms are blocks and prolongations. Yairi ${ }^{3}$ reported that, compared to the recovered group, the persistent group had a 5- to 8-month-older onset age, a longer time between onset and first consultation, and lower scores for comprehension and expressive ability in developmental testing. Also, boys tend to have a lower recovery rate than girls ${ }^{9-11)}$, although this difference did not reach a significant level.

In previous research, associations between characteristics of stuttering children and recovery were investigated using univariate analysis, which ignores the influence of other characteristics. Because of this, there is the possibility that reported associations may be confounded by other factors. In addition, it is unclear whether the relationship of a characteristic to recovery differs depending on the concurrent presence or absence of another factor.
In this longitudinal study, pre-treatment characteristics of stuttering children were surveyed at the time of first consultation at facilities where speech-language-hearing therapists treat stuttering. Characteristics studied include sex, onset age, time from onset, history of counseling for stuttering, age and condition of stuttering at time of consultation, and type of therapy. The condition of stuttering was followed, and the association between recovery from stuttering and each characteristic was examined after adjusting for mutual influence. In addition, taking sex as a non-modifiable factor and time from onset as a modifiable factor, we investigated whether characteristics related to recovery from stuttering differed according to levels of each factor (male/ female; time from onset $\leq 24$ months/>25 months). Based on the results of these investigations, it was clarified whether there are characteristics that can provide information useful to speech-languagehearing therapists in predicting the prognosis of treatment in stuttering children.

\section{Methods}

\section{Study subjects}

The cases were taken from 14 facilities where the first author or research collaborators were employed as speech-language-hearing therapists in charge of stuttering treatment. Between January 1992 and December 2007, 108 children consulted the 14 facilities for the first time and began treatment for childhood stuttering by speech-language-hearing therapists. One facility was located in the Kanto region (International University of Health and 
Welfare Clinic Medical Clinic - Speech-LanguageHearing Center), four in the Chubu region (Iso Hospital, Japan College of Rehabilitation and Welfare Professionals, Konan Kosei Hospital, Kuwana Rehabilitation Center for Children with Disabilities), seven in the Shikoku region (Kochi Medical School Hospital, Hosogi Hospital, Susaki Kuroshio Hospital, Noichi Chuo Hospital, Udaka ENT Clinic, Kamojima Hospital, Mino Tanaka Hospital), and two in the Kyushu region (Oita Rehabilitation Center for Children with Disabilities, Tenseido Clinic).

We excluded 11 cases from analysis because of complications due to mental retardation, language retardation, or expressive language disorder, and analyzed the remaining 97 cases ( 75 boys, 22 girls). Fifty-five subjects were examined directly at collaborating research institutions without passing through other medical institutions, whereas 34 subjects were examined after being referred from other medical institutions. Eight subjects had missing values for counseling history.

The follow-up of the cases was examined on May 11, 2009. For stuttering children whose treatment ended before the start of this research (April 2007), medical records were reviewed by the speechlanguage-hearing therapist in charge of their treatment, and anonymized information necessary for this research was collected. For children already receiving treatment for stuttering at the start of this research project and those who began treatment after the start of this research project, the speechlanguage-hearing therapist in charge of their treatment explained the goals of this research to the child's guardian and requested their participation in this research; consent was obtained from all subjects.

This research was performed with approval from the Kochi Medical School ethics committee.

\section{Study variables}

The items surveyed include: sex, onset age, age at first consultation at a collaborating research institution, calendar date at first consultation at a collaborating research institution, time from onset until first consultation at a collaborating research institution, counseling history prior to consultation at a collaborating research institution, condition of stuttering at time of first consultation at a collaborating research institution (stuttering developmental phase ${ }^{12-16)}$ and presence or absence of dyslalia), conditions other than stuttering (presence or absence of a non-stuttering disorder and developmental test findings), and the type of therapy used by the collaborating research institution's speech-language-hearing therapist (indirect approaches vs. direct approaches). Calendar date at first consultation at a collaborating research institution was included as a study variable in order to address influences of medical advancement on the recovery rates. With regard to the type of therapy, indirect approaches work on the premise that stuttering is best dealt with by changing the environment in which it develops; direct approaches specifically target speech output ${ }^{17}$.

Numerical variables were divided into two categories as follows. Calendar date of first consultation was divided at the median. Onset age was divided at the month of 24 because a previous study reported that the youngest onset age of the subjects with persistent stuttering was 24 months ${ }^{1)}$. Age at first consultation was divided at 36 months because the previous study reported that the mean age of the first consultation for the subjects who recovered from stuttering was 36 months $^{3)}$. Months post onset was divided at 24 months because recovery has been reported to be more difficult after 24 months $^{1,5}$. The stuttering developmental phase was dichotomized into phase 1 in which the feature of fluent periods is episodic and phases 2-4 in which the feature of fluent periods is chronic.

The severity of stuttering was evaluated by referring only to the symptom features of the developmental phase of stuttering ${ }^{12}$. The symptoms of respective phases were as follows: phase 1, syllable repetition, part-word repetition, or prolongation; phase 2, repetition, prolongation, block, or associated symptoms; phase 3, all symptoms except for avoidance of speech, elaborately developed symptomatology with postponement, starting, and release devices; phase 4, fully developed symptomatology with avoidance, postponement, starting, and release devices. At approximately 
3-month intervals, a speech-language-hearing therapist in charge of the child evaluated occurrences and frequencies of the respective symptoms as the child spoke freely in the examination room. When the child spoke little in the examination room, the guardian's reports on the occurrences and frequencies of stuttering symptoms in the child's daily activities were addressed. If the attending therapist perceived that the child exhibited no problem in terms of the symptom features of the stuttering developmental phase or the frequencies of respective symptoms were within normal ranges, the therapist judged that the child was recovered from the stuttering. The date of recovery was set as the date of the examination when the child was judged by the attending speech-language-hearing therapist to be recovered.

Of the items surveyed, developmental test results were excluded from the variables analyzed because only 37 subjects received developmental tests (38.1\% of subjects analyzed).

\section{Statistical analysis}

The observation period for the subjects was measured from the date of first consultation at a collaborating research institution. The date of end of the observation was defined as follows: the date of recovery for a subject who was judged to be recovered, the date of the last consultation with a speech-language-hearing therapist for a subject with whom the therapist could not make contact, and the examined date (May 11, 2009) for a subject who was still under treatment at the end of this research.

For univariate analysis, recovery rates were compared between categories for each variable, and differences were analyzed using a log-rank test. For multivariate analysis, a proportional hazards model was used to calculate the ratio of recovery rates, which reveals the relationship between each variable and recovery, while adjusting for the mutual influences of the variables.

After analyzing all subjects, the subjects were then stratified by sex and by time from onset until first consultation ( $<24$ months and $>24$ months).

Statistical analyses were performed using SPSS 11.0J (SPSS Japan, Tokyo, Japan). All tests were 2-tailed. The level of significance was set at 5\% .

\section{Results}

\section{Pre-treatment characteristics of subjects}

The average onset age of the subjects was 35.2 months (range, 12-58 months), average age at first consultation at a collaborating research institution was 55.7 months (range, 24-111 months), and average time from onset until first consultation at a collaborating research institution was 20.6 months (range, 0-75 months).

At the time of first consultation at a collaborating research institution, 44 subjects (45.4\%) were classified as having a stuttering developmental phase of 1,10 subjects (10.3\%) were diagnosed with dyslalia (including possible cases) and 34 subjects (35.1\%) received consultations from specialists before their first consultation at a collaborating research institution. Fifty subjects (51.5\%) received their first consultation at a collaborating research institution before August 2004. Eighty-nine subjects (91.8\%) received indirect therapy from a speech-languagehearing therapist at a collaborating research institution.

Fifty-five subjects (56.7\%) recovered during the follow-up period. The average time from onset until recovery or end of observation was 36.0 months (range, 5-83 months).

\section{Analyses performed on all subjects}

The results of univariate analysis are summarized in Table 1. No differences were found in recovery rate between categories in sex, consultation date, onset age, dyslalia, counseling history, or treatment method. Subjects aged 36 months or younger at the time of consultation at a collaborating research institution tended to have a higher recovery rate than subjects aged 37 months or older. Subjects who received consultations at collaborating research institutions within 24 months of onset also tended to have a higher recovery rate than subjects receiving consultations at 25 months after onset or later. Subjects with a stuttering developmental phase of 1 at the time of first consultation at a collaborating research institution had a significantly higher recovery rate than subjects with phase 2 or greater. 
Table 1 Crude recovery rates of children with stuttering according to categories of pretreatment characteristics (N=97)

\begin{tabular}{|c|c|c|c|c|c|}
\hline & $\begin{array}{c}\text { Number of } \\
\text { cases }\end{array}$ & $\begin{array}{c}\text { Person- } \\
\text { years }\end{array}$ & $\begin{array}{l}\text { Number of } \\
\text { recoveries }\end{array}$ & $\begin{array}{c}\text { Recovery } \\
\text { rate }\end{array}$ & $P$ value \\
\hline \multicolumn{6}{|l|}{ Sex } \\
\hline Females & 22 & 34.6 & 13 & 0.423 & \multirow{2}{*}{0.514} \\
\hline Males & 75 & 99.3 & 42 & 0.376 & \\
\hline \multicolumn{6}{|l|}{ Calendar date of first consultation } \\
\hline Before August 31, 2004 & 50 & 81.1 & 33 & 0.407 & \multirow{2}{*}{0.663} \\
\hline After September 1, 2004 & 47 & 52.8 & 22 & 0.421 & \\
\hline \multicolumn{6}{|l|}{ Onset age } \\
\hline 12-24 months & 14 & 14.5 & 8 & 0.552 & \multirow{2}{*}{0.199} \\
\hline 25-58 months & 83 & 119.5 & 47 & 0.393 & \\
\hline \multicolumn{6}{|l|}{ Age at first consultation } \\
\hline 24-36 months & 11 & 9.6 & 7 & 0.729 & \multirow{2}{*}{0.059} \\
\hline $37-111$ months & 86 & 124.4 & 48 & 0.386 & \\
\hline \multicolumn{6}{|l|}{ Time from onset until first consultation } \\
\hline 0-24 months & 60 & 83.3 & 40 & 0.480 & \multirow{2}{*}{0.098} \\
\hline 25-75 months & 37 & 50.6 & 15 & 0.296 & \\
\hline \multicolumn{6}{|l|}{ Stuttering developmental phase at time of first consultation } \\
\hline Phase 1 & 44 & 52.5 & 31 & 0.590 & \multirow{2}{*}{0.002} \\
\hline Phase 2-3 & 53 & 81.5 & 24 & 0.294 & \\
\hline \multicolumn{6}{|l|}{ Dyslalia } \\
\hline Absent & 87 & 118.2 & 50 & 0.423 & \multirow{2}{*}{0.527} \\
\hline Present including possible cases & 10 & 15.7 & 5 & 0.318 & \\
\hline \multicolumn{6}{|l|}{ Counseling history* ${ }^{*}$} \\
\hline Absent & 55 & 77.0 & 32 & 0.416 & \multirow{2}{*}{0.646} \\
\hline Present & 34 & 42.1 & 19 & 0.451 & \\
\hline \multicolumn{6}{|l|}{ Therapy } \\
\hline Indirect approach only & 89 & 124.4 & 53 & 0.430 & \multirow{2}{*}{0.349} \\
\hline Direct approach only and combination with indirect approach & 8 & 9.6 & 2 & 0.208 & \\
\hline
\end{tabular}

Table 2 Adjusted recovery rate ratio of children with stuttering by pretreatment characteristics, by sex

\begin{tabular}{|c|c|c|c|c|}
\hline \multirow[b]{2}{*}{ Age at first consultation, 37-111 months/24-36 months } & \multirow{2}{*}{$\begin{array}{l}\begin{array}{l}\text { Recovery rate } \\
\text { ratio, adjusted* }\end{array} \\
0.51\end{array}$} & \multicolumn{2}{|c|}{$\begin{array}{l}\text { 95\% confidence } \\
\text { interval }\end{array}$} & \multirow{2}{*}{$\begin{array}{c}\text { P Value } \\
0.110\end{array}$} \\
\hline & & 0.22 & 1.17 & \\
\hline Time from onset until first consultation, $25-75$ months/0-24 months & 0.78 & 0.41 & 1.48 & 0.441 \\
\hline Stuttering developmental phase at time of first consultation, Phase $2-3 /$ Phase 1 & 0.46 & 0.26 & 0.80 & 0.006 \\
\hline
\end{tabular}

*Adjusted for characteristics described in the table simultaneously.

Table 2 shows the results when age at first consultation, time from onset until consultation, and stuttering developmental phase at time of consultation were simultaneously entered into a proportional hazards model. A stuttering developmental phase of 1 at the time of consultation was associated with a significantly higher recovery rate.

\section{Analyses by sex}

The results of univariate analysis according to sex are shown in Table 3. Female subjects aged 36 months or younger at the time of first consultation at a collaborating research institution had a significantly higher recovery rate than subjects aged 37 months or older. Likewise, female subjects who received consultations at collaborating research institutions within 24 months of onset also had a significantly higher recovery rate than female subjects who received consultations at 25 months or later after onset. Female subjects with a stuttering developmental phase of 1 at the time of consultation at a collaborating research institution had a significantly higher recovery rate than subjects with phase 2 or greater. Male subjects with a stuttering 
Table 3 Crude recovery rates of children with stuttering according to categories of pretreatment characteristics, by sex

\begin{tabular}{|c|c|c|c|c|c|}
\hline & $\begin{array}{l}\text { Number of } \\
\text { cases }\end{array}$ & $\begin{array}{c}\text { Person- } \\
\text { years }\end{array}$ & $\begin{array}{l}\text { Number of } \\
\text { recoveries }\end{array}$ & $\begin{array}{c}\text { Recovery } \\
\text { rate }\end{array}$ & $P$ value \\
\hline \multicolumn{6}{|l|}{ Females $(\mathrm{N}=22)$} \\
\hline \multicolumn{6}{|l|}{ Onset age } \\
\hline 12-24 months & 5 & 5.3 & 3 & 0.566 & \multirow{2}{*}{0.350} \\
\hline 25-58 months & 17 & 7.3 & 10 & 0.340 & \\
\hline \multicolumn{6}{|l|}{ Age at first consultation } \\
\hline 24-36 months & 3 & 1.0 & 3 & 3.000 & \multirow{2}{*}{$<0.001$} \\
\hline $37-111$ months & 19 & 33.6 & 10 & 0.298 & \\
\hline \multicolumn{6}{|l|}{ Time from onset until first consultation } \\
\hline 0-24 months & 11 & 12.6 & 9 & 0.556 & \multirow{2}{*}{0.020} \\
\hline $25-75$ months & 11 & 22.1 & 4 & 0.181 & \\
\hline \multicolumn{6}{|l|}{ Stuttering developmental phase at time of first consultation } \\
\hline Phase 1 & 9 & 6.7 & 7 & 1.045 & \multirow{2}{*}{0.001} \\
\hline Phase $2-3$ & 13 & 27.9 & 6 & 0.215 & \\
\hline \multicolumn{6}{|l|}{ Dyslalia } \\
\hline Absent & 19 & 27.6 & 13 & 0.471 & \multirow{2}{*}{0.077} \\
\hline Present including possible cases & 3 & 7.0 & 0 & & \\
\hline \multicolumn{6}{|l|}{ Counseling history } \\
\hline Absent & 13 & 20.7 & 9 & 0.435 & \multirow{2}{*}{0.313} \\
\hline Present & 7 & 10.4 & 2 & 0.192 & \\
\hline \multicolumn{6}{|l|}{ Therapy } \\
\hline Indirect approach only & 20 & 31.9 & 13 & 0.408 & \multirow{2}{*}{0.321} \\
\hline Direct approach only and combination with indirect approach & 2 & 2.8 & 0 & & \\
\hline \multicolumn{6}{|l|}{ Males $(\mathrm{N}=75)$} \\
\hline \multicolumn{6}{|l|}{ Onset age } \\
\hline 12-24 months & 9 & 9.2 & 5 & 0.541 & \multirow{2}{*}{0.362} \\
\hline $25-58$ months & 66 & 90.1 & 37 & 0.411 & \\
\hline \multicolumn{6}{|l|}{ Age at first consultation } \\
\hline 24-36 months & 8 & 8.6 & 4 & 0.465 & \multirow{2}{*}{0.694} \\
\hline 37-111 months & 67 & 90.8 & 38 & 0.419 & \\
\hline \multicolumn{6}{|l|}{ Time from onset until first consultation } \\
\hline 0-24 months & 49 & 70.7 & 31 & 0.438 & \multirow{2}{*}{0.941} \\
\hline 25-75 months & 26 & 28.6 & 11 & 0.385 & \\
\hline \multicolumn{6}{|l|}{ Stuttering developmental phase at time of first consultation } \\
\hline Phase 1 & 35 & 45.8 & 24 & 0.524 & \multirow{2}{*}{0.097} \\
\hline Phase $2-3$ & 40 & 53.5 & 18 & 0.336 & \\
\hline Dyslalia & & & & & \\
\hline Absent & 68 & 90.6 & 37 & 0.408 & 0410 \\
\hline Present including possible cases & 7 & 8.7 & 5 & 0.575 & 0.418 \\
\hline Counseling history & & & & & \\
\hline Absent & 42 & 56.3 & 23 & 0.409 & \\
\hline Present & 27 & 31.7 & 17 & 0.536 & 0.297 \\
\hline Therapy & & & & & \\
\hline Indirect approach only & 69 & 92.5 & 40 & 0.432 & \\
\hline Direct approach only and combination with indirect approach & 6 & 6.8 & 2 & 0.294 & 0.649 \\
\hline
\end{tabular}

developmental phase of 1 at the time of consultation at a collaborating research institution tended to have a higher recovery rate than subjects with phase 2 or greater.

Characteristics that were determined to be associated with recovery in either male or female subjects on univariate analysis (age at first consultation, time from onset until first consultation, and stuttering developmental phase at time of consultation) were simultaneously entered into a proportional hazards model, and the adjusted results are shown in Table 4. After adjusting for the mutual 
Table 4 Adjusted recovery rate ratio of children with stuttering by pretreatment characteristics, by sex

\begin{tabular}{|c|c|c|c|c|}
\hline & $\begin{array}{l}\text { Recovery rate } \\
\text { ratio, adjusted* }\end{array}$ & \multicolumn{2}{|c|}{$\begin{array}{l}\text { 95\% confidence } \\
\text { interval }\end{array}$} & P Value \\
\hline \multicolumn{5}{|l|}{ Females $(\mathrm{N}=22)$} \\
\hline Age at first consultation, 37-111 months/24-36 months & 0.14 & 0.02 & 0.91 & 0.040 \\
\hline Time from onset until first consultation, 25-75 months/0-24 months & 0.50 & 0.11 & 2.27 & 0.366 \\
\hline $\begin{array}{l}\text { Stuttering developmental phase at time of first consultation, Phase 2-3/ } \\
\text { Phase } 1\end{array}$ & 0.21 & 0.05 & 0.95 & 0.042 \\
\hline \multicolumn{5}{|l|}{ Males $(\mathrm{N}=75)$} \\
\hline Age at first consultation, 37-111 months/24-36 months & 0.76 & 0.26 & 2.240 & 0.620 \\
\hline Time from onset until first consultation, $25-75$ months/0-24 months & 1.06 & 0.51 & 2.200 & 0.874 \\
\hline $\begin{array}{l}\text { Stuttering developmental phase at time of first consultation, Phase 2-3/ } \\
\text { Phase } 1\end{array}$ & 0.59 & 0.31 & 1.100 & 0.096 \\
\hline
\end{tabular}

*Adjusted for characteristics described in the table simultaneously.

influences of these three variables, an age of 36 months or younger at the time of consultation and a stuttering developmental phase of 1 at the time of consultation were associated with a significantly higher recovery rate in female subjects. In male subjects, a stuttering developmental phase of 1 at the time of consultation tended to be associated with a higher recovery rate.

\section{Analyses by time from onset to consultation}

The results of univariate analysis according to duration from onset to consultation are shown in Table 5. In stuttering children who received consultations at collaborating research institutions within 24 months of onset, subjects with an onset age of 24 months or younger tended to have a higher recovery rate than those aged 25 months or older, and subjects with a stuttering developmental phase of 1 at the time of first consultation had a significantly higher rate of recovery than subjects with phase 2 or higher. In subjects who received consultations at collaborating research institutions 25 or more months after onset, male subjects tended to have a higher recovery rate than female subjects.

Characteristics that were associated with recovery in subjects receiving a consultation either within 24 months of onset or 25 or more months after onset on univariate analysis (sex, onset age, and stuttering developmental phase at first consultation) were simultaneously entered into a proportional hazards model; the adjusted results are shown in Table 6 . In stuttering children who received consultations within 24 months of onset, an onset age of 24 months or younger and a stuttering developmental phase of 1 at the time of first consultation were associated with significantly higher recovery rates even after adjusting for the mutual influences of the variables. Female subjects also tended to have a higher recovery rate than male subjects. In stuttering children who received consultations 25 months or later after onset, the relationship between sex and recovery disappeared.

\section{Discussion}

The results of multivariate analysis using all subjects suggest that stuttering developmental phase is a predictive factor of recovery independent of time from onset until first consultation, which is known as a predictive factor of stuttering recovery ${ }^{3)}$. Stuttering developmental phase is a consistent predictive factor of recovery even in analyses stratified by sex. In reports about the relationship between severity of stuttering and lack of recovery (persistence), having blocks and prolongations as major symptoms or having a high proportion of blocks was associated with persistent stuttering ${ }^{7,8,17}$. Considering blocks and prolongations in this research, the recovery rate was higher in phase 1 cases (which display only prolongations), which is consistent with the previous reports.

In analyses stratified by time from onset, stuttering developmental phase was a predictive indicator of stuttering recovery only in the subjects that received consultation at a stuttering treatment facility within 24 months of onset. If children receive 
Table 5 Crude recovery rates of children with stuttering according to pretreatment characteristics, by period from onset to first consultation

\begin{tabular}{|c|c|c|c|c|c|}
\hline & $\begin{array}{c}\text { Number of } \\
\text { cases }\end{array}$ & $\begin{array}{c}\text { Person- } \\
\text { years }\end{array}$ & $\begin{array}{l}\text { Number of } \\
\text { recoveries }\end{array}$ & $\begin{array}{c}\text { Recovery } \\
\text { rate }\end{array}$ & $\mathrm{P}$ value \\
\hline \multicolumn{6}{|l|}{ Within 24 months $(\mathrm{N}=60)$} \\
\hline \multicolumn{6}{|l|}{ Sex } \\
\hline Females & 11 & 12.6 & 9 & 0.714 & \multirow{2}{*}{0.168} \\
\hline Males & 49 & 70.7 & 31 & 0.438 & \\
\hline \multicolumn{6}{|l|}{ Onset age } \\
\hline 12-24 months & 8 & 5.90 & 5 & 0.847 & \multirow{2}{*}{0.067} \\
\hline 25-58 months & 52 & 77.4 & 35 & 0.452 & \\
\hline \multicolumn{6}{|l|}{ Age at first consultation } \\
\hline 24-36 months & 11 & 9.6 & 7 & 0.729 & \multirow{2}{*}{0.130} \\
\hline 37-111 months & 49 & 73.8 & 33 & 0.447 & \\
\hline \multicolumn{6}{|l|}{ Time from onset until first consultation } \\
\hline $0-6$ months & 24 & 29.5 & 18 & 0.610 & \multirow{2}{*}{0.120} \\
\hline $7-24$ months & 36 & 53.8 & 22 & 0.409 & \\
\hline \multicolumn{6}{|l|}{ Stuttering developmental phase at time of first consultation } \\
\hline Phase 1 & 30 & 38.9 & 25 & 0.643 & \multirow{2}{*}{0.018} \\
\hline Phase $2-3$ & 30 & 44.4 & 15 & 0.338 & \\
\hline \multicolumn{6}{|l|}{ Dyslalia } \\
\hline Absent & 55 & 76.1 & 38 & 0.499 & \multirow{2}{*}{0.409} \\
\hline Present including possible cases & 5 & 7.2 & 2 & 0.278 & \\
\hline \multicolumn{6}{|l|}{ Counseling history } \\
\hline Absent & 31 & 43.7 & 22 & 0.503 & \multirow{2}{*}{0.798} \\
\hline Present & 23 & 30.4 & 16 & 0.526 & \\
\hline \multicolumn{6}{|l|}{ Therapy } \\
\hline Indirect approach only & 57 & 76.9 & 39 & 0.507 & \multirow{2}{*}{0.222} \\
\hline Direct approach only and combination with indirect approach & 3 & 6.4 & 1 & 0.156 & \\
\hline \multicolumn{6}{|l|}{ More than 25 months $(\mathrm{N}=37)$} \\
\hline \multicolumn{6}{|l|}{ Sex } \\
\hline Females & 11 & 22.1 & 4 & 0.181 & \multirow{2}{*}{0.092} \\
\hline Males & 26 & 28.6 & 11 & 0.385 & \\
\hline \multicolumn{6}{|l|}{ Onset age } \\
\hline 12-24 months & 6 & 8.6 & 3 & 0.349 & \\
\hline 25-58 months & 31 & 42.0 & 12 & 0.286 & 0.895 \\
\hline Age at first consultation & & & & & \\
\hline 41-72 months & 20 & 27.7 & 9 & 0.325 & \\
\hline 73-111 months & 17 & 22.9 & 6 & 0.262 & 0.664 \\
\hline Time from onset until first consultation & & & & & \\
\hline 25-36 months & 17 & 25.5 & 6 & 0.325 & \\
\hline 37-75 months & 20 & 25.1 & 9 & 0.359 & 0.381 \\
\hline Stuttering developmental phase at time of first consultation & & & & & \\
\hline Phase 1 & 14 & 13.6 & 6 & 0.441 & 0142 \\
\hline Phase $2-3$ & 23 & 37.1 & 9 & 0.243 & 0.142 \\
\hline Dyslalia & & & & & \\
\hline Absent & 32 & 42.1 & 12 & 0.285 & 701 \\
\hline Present including possible cases & 5 & 8.5 & 3 & 0.353 & 0.721 \\
\hline Counseling history & & & & & \\
\hline Absent & 24 & 33.3 & 10 & 0.300 & 0713 \\
\hline Present & 11 & 11.7 & 3 & 0.256 & 0.713 \\
\hline Therapy & & & & & \\
\hline Indirect approach only & 32 & 47.5 & 14 & 0.295 & 0810 \\
\hline Direct approach only and combination with indirect approach & 5 & 3.1 & 1 & 0.323 & 0.810 \\
\hline
\end{tabular}


Table 6 Adjusted recovery rate of children with stuttering by pretreatment characteristics, by period from onset to first consultation

\begin{tabular}{|c|c|c|c|c|}
\hline & $\begin{array}{l}\text { Recovery rate } \\
\text { ratio, adjusted* }\end{array}$ & \multicolumn{2}{|c|}{$\begin{array}{l}\text { 95\% confidence } \\
\text { interval }\end{array}$} & P Value \\
\hline \multicolumn{5}{|l|}{ Within 24 months from the onset $(\mathrm{N}=60)$} \\
\hline Sex, Males/Females & 0.49 & 0.22 & 1.06 & 0.068 \\
\hline Onset age, $25-58$ months/12-24 months & 0.34 & 0.13 & 0.91 & 0.032 \\
\hline $\begin{array}{l}\text { Stuttering developmental phase at time of first consultation, Phase 2-3/ } \\
\text { Phase } 1\end{array}$ & 0.41 & 0.21 & 0.81 & 0.010 \\
\hline \multicolumn{5}{|l|}{ More than 25 months from the onset $(\mathrm{N}=37)$} \\
\hline Sex, Males/Females & 0.33 & 0.07 & 1.64 & 0.176 \\
\hline Onset age, $25-58$ months $/ 12-24$ months & 0.62 & 0.15 & 2.58 & 0.512 \\
\hline $\begin{array}{l}\text { Stuttering developmental phase at time of first consultation, Phase 2-3/ } \\
\text { Phase } 1\end{array}$ & 0.53 & 0.16 & 1.78 & 0.304 \\
\hline
\end{tabular}

${ }^{*}$ Adjusted for characteristics described in the table simultaneously by a cox proportional hazards model

a consultation at a treatment facility during this time period, it is possible for therapists to predict treatment progress based on sex, onset age, and developmental phase; this will improve the explanation about treatment policies to guardians. In order to increase the number of stuttering children receiving consultations at stuttering treatment facilities within 24 months of onset, it is necessary to encourage children's guardians, day care facility employees, and pediatric medical staff to introduce stuttering children to treatment facilities without delay following onset. In the American guidebook "If Your Child Stutters - A Guide for Parents"5), repetition of polysyllables and/or prolongations are reported to be warning signs of stuttering, and the guidebook recommends that a child should receive a consultation with a specialist. We believe that the creation of such a guidebook in Japan would be useful.

Among children who received a consultation at a collaborating research institution within 24 months of onset, girls tended to have a higher recovery rate than boys, although this did not reach a significant level. This sex difference in recovery rate indicates that certain sex-related genetic factors may be associated with recovery. Ambrose ${ }^{9}$ indicated that in order to understand the higher recovery rate of female subjects, a linkage analysis of the parents from whom the susceptibility to stuttering was inherited is necessary, rather than analyzing the stuttering children themselves. In addition, sex differences in brain activity indicated in research on stuttering adults ${ }^{11)}$ may aid in explaining the sex differences in childhood stuttering recovery rates. Sato ${ }^{18)}$ compared brain activity between 12 stuttering school children aged 6-12 years old and 8 stuttering children aged 3-5 years old by brain oximetry with near infrared spectroscopy and reported that a connection between stuttering and functional aberrations of the auditory area was observable in the stuttering children group. We believe that it would be useful to examine sex differences in brain activity related to stuttering using this measurement technique.

\section{Limitations of this research}

First, recovery was judged based on perceived evaluation by the attending therapist in terms of occurrences and frequencies of the stuttering symptoms. The diagnosis of stuttering recovery is usually made by recording a child's speech and determining the frequency of core symptoms in the speech (repetition of syllables, repetition of language sections, prolongations, and blocks). A frequency of less than $3 \%$ is considered to be normal. It is necessary to confirm the correspondence between the perceived evaluation according to the symptom features of the stuttering developmental phase and the objective measurement of the frequencies of core symptoms.

Second, the reason we were unable to find factors relating to recovery in children who received 
consultations at collaborating research institutions after a significant amount of time had elapsed since onset may be because this group contained a disproportionate number of intractable cases. If we were able to identify, survey, and follow-up all stuttering children born in a community, we would be able to examine the influence of this selection bias.

Third, 24 of the research participants (24.7\%) stopped visiting the collaborating research institutions during the observation period; therefore, it is necessary to examine the influence of these withdrawals. When the analysis was conducted only for the 73 subjects who either recovered during the observation period or were still receiving therapy at the end of the observation period, the differences in recovery rates between categories of the subjects' characteristics were essentially the same as those presented in Table 1 (the results upon request to the authors). There were no significant differences in sex distribution, developmental phase distribution, average onset age, or average age at first consultation at a collaborating research institution between the 73 children who either recovered during the observation period or were still receiving therapy at the end of the observation period and the 24 children who withdrew from the study during the observation period. In addition, between the withdrawals and those who did not withdraw, there was no difference in the proportion of children who were observed for 24 months or more since the stuttering onset $70.8 \%$ in the withdrawals vs. $74.0 \%$ in those who did not withdraw). The period of 24 months since the onset is the time when the cumulative recovery rate is reported to plateau ${ }^{1,5}$. According to those similarities, it is unlikely that the observed associations between recovery and the characteristics of stuttering children were biased by the presence of withdrawals.

Finally, spontaneous recovery from stuttering is well known ${ }^{19}$, and it is thought that children who spontaneously recovered were present among the subjects of this study. It is necessary to keep in mind that the results of this study indicate factors relating to recovery when recovery due to successful treatment and spontaneous recovery are not distinguished.

\section{Conclusions}

The relationship between stuttering recovery and pre-treatment characteristics of stuttering children was examined by performing a longitudinal study of stuttering children receiving consultations at stuttering treatment facilities. Characteristics that were associated with recovery were found only when children received consultations at a treatment facility within 24 months of onset. Onset age of 24 months or younger, female sex, and a stuttering developmental phase of 1 were associated with a high recovery rate in a mutually independent manner. The period within 24 months of onset is not just the time when stuttering is easiest to treat (as indicated in previous research), it is also important as the period when factors relating to stuttering recovery are observable. It is possible to predict the prognosis of treatment begun during this period based on onset age, sex, and pre-treatment stuttering developmental phase.

\section{Appendix}

The research collaborators are S. Niimi and N. Maehara, International University of Health and Welfare Clinic Medical Clinic $\cdot$ Speech-Language-Hearing Center, Tochigi; T. Iso and Y. Mitsuta, Iso Hospital, Aichi; T. Tanahashi, M. Tsuchiya, and S. Tajima, Japan College of Rehabilitation and Welfare Professionals, Aichi; Y. Katou, M. Matsuoka, and K. Nakanishi, Konan Kosei Hospital, Aichi; E. Matsuoka and K. Murata, Kuwana Rehabilitation Center for Children with Disabilities, Mie; T. Sugiura, H. Wakiguchi, M. Miyake, and S. Kishimoto, Kochi Medical School Hospital, Kochi; H. Nakaya, Kochi Rehabilitation Institute, Kochi; K. Hashimoto and T. Nagae, Hosogi Hospital, Kochi; S. Tamura and M. Matsuo, Susaki Kuroshio Hospital, Kochi; M. Kumon, F. Toyonaga, A. Katou, and Y. Morishita, Noichi Chuo Hospital, Kochi; J. Udaka and H. Nagashima, Udaka ENT Clinic, Tokushima; T. Tsuchihash and K. Okada, Kamojima Hospital, Tokushima; T. Tanaka, K Miyata, and K. Takeda, Mino Tanaka Hospital, Tokushima; T. Satake, J. Urashima, and M. Sogo, Oita Rehabilitation Center for Children with Disabilities, Oita; M. Shiiba and H. Hirata, Tenseido Clinic, Miyazaki.

\section{References}

1) Mansson H: Childhood stuttering incidence and 
development. J Fluency Disord, 25: 47-57, 2000.

2) Andrews $G$ and Harris $M$ : The natural history of stuttering. The Syndrome of Stuttering (edited by Andrews G, et al), Spastics Society Medical Education and Information Unit in Association with William Heinemann Medical Books, London, pp 30-34, 1964.

3) Yairi E, Ambrose NG, Paden EP, et al: Predictive factors of persistence and recovery - Pathways of childhood stuttering-. J Commun Disord, 29: 51-77, 1996.

4) Forster DC and Webster WG: Speech-motor and inter hemispheric relations in recovered and persistent stuttering. Dev Neuropsychol, 19: 125-145, 2001.

5) Ainsworth S, Conture EG, Dell C, et al: Does my child stutter? If Your Child Stutters - A Guide for Parents, 7th ed (edited by Fraser J), Stuttering Foundation, Memphis, pp 9-20, 2008.

6) Kalinowski J and Saltuklaroglu T: The road to efficient and effective management of stuttering - Information for physicians-. Curr Med Res Opin, 20: 509-515, 2004.

7) Van Riper C: Phenomenology: Overt features. The Nature of Stuttering, 2nd ed (edited by Van Riper C), PrenticeHall, America, pp 111-143, 1982.

8) Conture E: Assessment and evaluation. Stuttering, 2nd ed (edited by Martin FN), Englewood Cliffs, New Jersey, America, pp 35-84, 1990.

9) Ambrose NG, Cox NJ and Yairi E: The genetic basis of persistence and recovery in stuttering. J Speech Lang Hear Res, 40: 567-580, 1997.

10) Yairi E and Ambrose NG: Early childhood stuttering Persistency and recovery rates. J Speech Lang Hear Res, 42: 1097-1112, 1999.

11) Ingham RJ, Fox PT, Ingham JC, et al: Brain correlates of stuttering and syllable production - Gender comparison and replication. J Speech Lang Hear Res, 47: 321-341, 2004.
12) A stuttering evaluation subcommittee of the Japan Society of Logopedics and Phoniatrics, Moriyama H, Ozawa E, et al: About stuttering evaluation <draft plan>. Jpn J Logop Phoniatr, 22: 194-208, 1981.

13) Bloodstein O: The Development of Stuttering: I. Changes in Nine Basic Features. J Speech Hear Disord, 25: 219237, 1960.

14) Bloodstein O: The development of stuttering: II. developmental phases. J Speech Hear Disord, 25: 366376, 1960.

15) Bloodstein O: The development of stuttering: III. theoretical and clinical implications. J Speech Hear Disord, 26: 67-82, 1961.

16) Luper HL and Mulder RL: Diagnosis and evaluation of the child who stutters. STUTTERING - Therapy for Children, Englewood Cliffs, New Jersey, pp 13-35, 1964.

17) Ward D: The aetiology and treatment of developmental stammering in childhood. Arch Dis Child, 93: 68-71, 2008.

18) Sato $Y$, Mori K, Koizumi $T$, et al: Functional lateralization during phonological word processing in children who stutter -Measured by near-infrared spectroscopy. Jpn J Logop Phoniatr, 47: 384-389, 2006.

19) Sheehan JG and Martyn MM: Stuttering and its disappearance. J Speech Hear Res, 13: 279-289, 1970.

論文別刷請求先：干781-1102 高知県土佐市高岡町乙 1139-3 高知リハビリテーション学院言語 療法学科 塩見将志 